\title{
Determination of Charring Thickness of Wood by Residual Strength Analysis
}

\author{
Min Ji Kim, Sejong Kim, Chul-ki Kim, and Kug Bo Shim * \\ This study was conducted to propose an accurate measurement method of \\ charred thickness in structural glued laminated timber (glulam) exposed to \\ standardized fire temperature conditions for evaluation of the fire resistance \\ of Japanese larch (Larix kaempferi) structural glulam. The compressive \\ strength of the test piece collected from the structural glulam exposed to the \\ standardized fire temperature for two hours was analyzed. The results \\ showed that there was residual strength of $14 \%$ in the boundary area between \\ sound and charred part. Therefore, the thickness of charred part should be \\ calculated as approximately $4.5 \mathrm{~mm}$ less than what is measured visually. The \\ cell wall thickness between sound-, boundary-, and charred-part exposed to \\ high temperature was observed under a microscope. Higher temperature \\ resulted in a thinner tracheid cell wall, and the radial tissue was broken down. \\ The transformation of the boundary part of these microstructures progressed \\ gradually until full carbonization of wood occurred. Based on compressive \\ strength tests and microscopic observation in the boundary part of specimens \\ exposed to high temperature, the current visual assessment of charred \\ thickness measurement is safe in terms of structural aspect but not efficient \\ in terms of wood utilization point of view due to exception of load carrying \\ area of the member.
}

DOI: 10.15376/biores.17.1.1485-1493

Keywords: Charred thickness; Fire-resistant test; Residual compressive strength; Visual determination of charred thickness

Contact information: Department of Forest Products, National Institute of Forest Science, Seoul 02455, Republic of Korea; *Corresponding author: kbshim@korea.kr

\section{INTRODUCTION}

Reducing the concentration of greenhouse gases in the atmosphere is a challenge for the future of humankind. The use of building materials for wood is expected to contribute to mitigating climate change by replacing 'carbon-intensive materials' such as cement and steel that emit large amounts of greenhouse gases in the production, processing, and transportation process. In developed countries in Europe and North America, such as Austria and Norway, interest in wooden construction is growing. Competition for high-rise wooden buildings is underway to showcase the technology of wooden architecture.

In the field of construction, safety against fire is the first consideration when wood or engineering wood are utilized as structural materials. The building must secure time for residents to evacuate safely in the event of a fire, which is called the fire resistance time. Fire resistance time of building materials is expressed as fire resistance performance. In Korea, buildings between five and twelve stories must have two hours fire resistance performance. The building where a fire has broken out should not collapse for two hours. The structural members need to support the building safely to secure times for residents' evacuation and allow the fire to be extinguished. 
The fire resistance performance of wood building materials is evaluated according to the load bearing capacity of materials exposed to standardized fire temperature conditions that reach $800{ }^{\circ} \mathrm{C}$ in 20 minutes and $1000{ }^{\circ} \mathrm{C}$ in 90 minutes. In other words, the amount of sound wood that is not carbonized and remains in its original state to support the load of the building under the standardized fire temperature conditions is assessed. Therefore, the charred depth in which wood is carbonized during the required fire-resistant time is measured, and the fire resistance performance is determined. In the case of Japanese larch, which is often used for structural purposes in Korea, the charring rate is calculated as $0.6 \mathrm{~mm}$ per minute (KSF 1611-3 2008). To secure two-hour fire resistance performance of Japanese larch wood, theoretically, $72 \mathrm{~mm}$ of wood should be estimated to be carbonized in one direction, and the required cross-sectional area should be expanded at least to 72 $\mathrm{mm}$. However, the charred thickness measured from two-hour fire resistance experiment is $80 \mathrm{~mm}$, which is the necessary additional thickness in one direction of structural member to be recognized as two-hour fire resistance performance. This is because the thickness of carbonization is determined by visual inspection of the color change of wood.

A charred layer is a part of wood exposed to high temperature and has been broken down by heat such that only carbon remains (KSF 1611-3 2008). When exposed to high temperature, the cell wall components such as cellulose, hemicellulose, and lignin are subjected to thermal degradation by heat, resulting in poor mechanical performance as wood. When exposed to high temperatures above $100{ }^{\circ} \mathrm{C}$, the performance reduction of wood varies depending on the wood's moisture content, high-temperature exposure period, and species (Ragland and Aerts 1991). When exposed to temperatures above $100{ }^{\circ} \mathrm{C}$, the decomposition of polysaccharides begins and chemical bonds in cell wall components begin to break in proportion to the exposure temperature. When exposed to temperatures in the range 100 to $200{ }^{\circ} \mathrm{C}$, water vapor and carbon dioxide, which are non-flammable substances, and very small amounts of formic acid and acetic acid are generated by dehydration. At temperatures above $200{ }^{\circ} \mathrm{C}$, cellulose decomposes and produces tar or flammable volatile substances that escape into the surrounding atmosphere. Combustible volatile substances are mixed with air, and the temperature rises to the flash point (Kim et al. 2019). Carbonization of wood is defined as when the temperature reaches $300{ }^{\circ} \mathrm{C}$, and the estimation results of the charred layer are consistent with the charring thickness measurement by visual observation (White 2000). When the temperature reaches 300 to $450{ }^{\circ} \mathrm{C}$, cellulose is changed to irregular forms; lignin finally breaks down, with the release of volatile compounds from the wood (Xing and Li 2014). When the temperature reaches $450{ }^{\circ} \mathrm{C}$ or higher, all volatile substances in the wood are burned and only carbon remains (Wang 2010). However, the exposure time and the charring rate are proportional under the continuous high temperatures; the generated charred layer prevents the spread of fire into the wood (Xu et al. 2015).

Currently, the charred layer of wood is defined as the layer in which only carbon content remains (KSF 1611-3 2008). However, the charred thickness of wood includes the boundary part between sound and charred wood. It is rational to estimate the charred thickness of wood by fire resistance performance of wood, which can support the load of buildings to evaluate fire resistance performance of the member, rather than by the change the color of the wood member. In particular, changes in the performance of wood building materials with respect to temperature can be determined by weakening the load carrying capacity or changes in the microstructure of wood.

This study determined the exact thickness of the charred part through compressive strength and optical microscope analysis of the wood cell wall of Japanese larch structural 
glued laminated beam exposed to the standardized fire temperature conditions for 2 hours under the $20 \mathrm{kN} / \mathrm{m}$ dead load. Accordingly, the suggested assessment method of the charred thickness measurement might contribute to the efficient use of wood building materials by increasing the sound part of the structural timber.

\section{EXPERIMENTAL}

\section{Materials}

The structural glued laminated timber, made of Japanese larch (Larix kaempferi), was selected as the high temperature exposure specimen (Fig. 1). The grade of the glued laminated timber was $10 \mathrm{~S}-30 \mathrm{~B}(\mathrm{KSF} 3021-2013)$, which means that the MOE is $10 \mathrm{GPa}$ and the allowable stress is $30 \mathrm{MPa}$. Compressive strength test specimens (30 x 30 x $50 \mathrm{~mm}$ ) including charred, boundary, and sound part were prepared from the cross section of structural glued laminated timber (original cross section $240(\mathrm{~W})$ x $420(\mathrm{H}) \mathrm{mm}$ ). The glued laminated timber was fire resistance tested under standardized fire temperature conditions under bending load $(20 \mathrm{kN} / \mathrm{m})$ for $2 \mathrm{~h}$. After the compressive strength test (ASTM D14314(2018)), samples were prepared to observe thermal changes of the cell wall caused by high temperature.
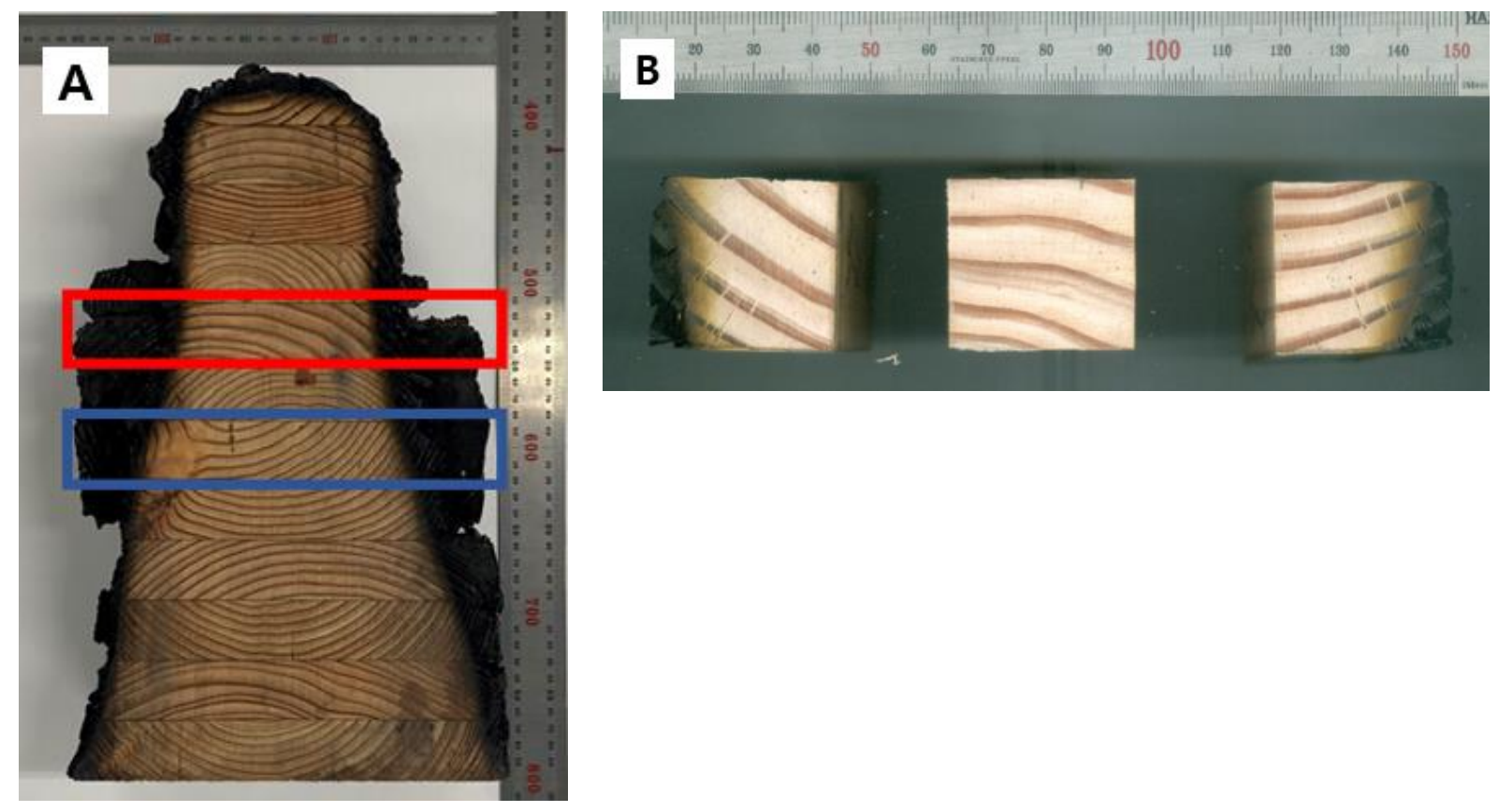

Fig. 1. Cross section of glued laminated timber beam after 2-h fire resistant test under bending load. A: Sample of whole, B: Compressive testing specimen from the same lamina

Temperature changes over time in the standardized fire temperature condition are shown in Fig. 2 and calculated with Eq. 1,

$$
T-T_{0}=345 \log _{10}(8 t+1)
$$

where $T$ is maximum fire temperature $\left(1047.8^{\circ} \mathrm{C}\right), T_{0}$ is initial fire temperature $\left(51.8{ }^{\circ} \mathrm{C}\right)$, and $t$ is fire test time $(120 \mathrm{~min})$. 


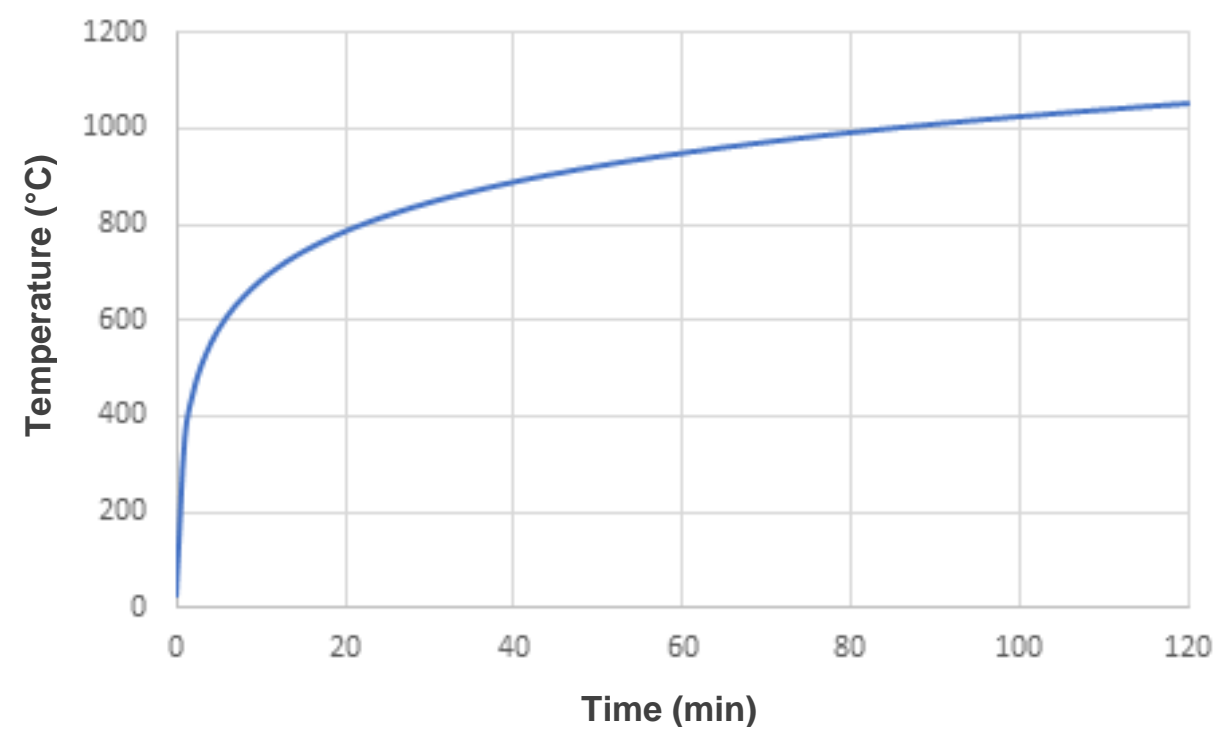

Fig. 2. Standardized fire temperature condition curve

\section{Methods}

Compressive strength test and charred area measurement

Compressive strength of charred wood and sound areas was compared to assess the changes caused by charred, boundary, and sound parts of glued laminated timber exposed to standardized fire conditions (Fig. 3). In order to minimize variations between specimens due to density, moisture content, average annual ring width, etc. of wood, the compressive strength of sound specimen (sample without charred layer) and charred specimen (sample with charred layer) were measured in the same laminar system (Table 1). The size of compressive strength test specimen was $30 \times 30 \times 50 \mathrm{~mm}$ according to ASTM D143-14 (2018) (Fig. 3). At this time, the targeted cross-sectional area of the charred sample (test piece including the charred part) was $30 \times 30 \mathrm{~mm}$. The cross-sectional area of the sound sample (sound part of the charred specimen) was measured using the Image J, Image Processing and Analysis software in Java, and applied to the average cross-sectional area calculation.

Image $\mathrm{J}$ is a program that enables dimensional measurements including area of the samples. The compressive strength test specimen was stored for several days in a constant temperature and humidity chamber (temperature $20 \pm 2{ }^{\circ} \mathrm{C}$, relative humidity $65 \pm 3 \%$ ) to reach constant weight (equilibrium moisture content $7.9 \%$ ) and then tested under constant temperature and humidity conditions (temperature $20 \pm 2{ }^{\circ} \mathrm{C}$, relative humidity $65 \pm 3 \%$ ) with a universal testing machine (Instron, Waltham, MA, USA). The load speed was set to $1 \mathrm{~mm} / \mathrm{min}$. to reach failure within 4 to $6 \mathrm{~min}$. The compressive strength was calculated by Eq. 2, as follows,

Compressive strength $(\mathrm{Pa})=\frac{\text { Compressive load }(\mathrm{N})}{\text { Area including sound and boundary layer }\left(m^{2}\right)}$

\section{Observation of cellular tissue changes caused by carbonization}

To observe the change in cellular tissue caused by carbonization, a sample containing all the sound, boundary, and charred layer was selected. The specimen was impregnated with PEG. A cross section for microscopic observation was prepared using a 
sliding microtome. After dyeing with $1 \%$ safranin, samples were observed with an optical microscope (observation magnification: x5, x10, x20). The thickness of the latewood tracheid wall by sound, boundary, and charred layers from 30 samples was measured.

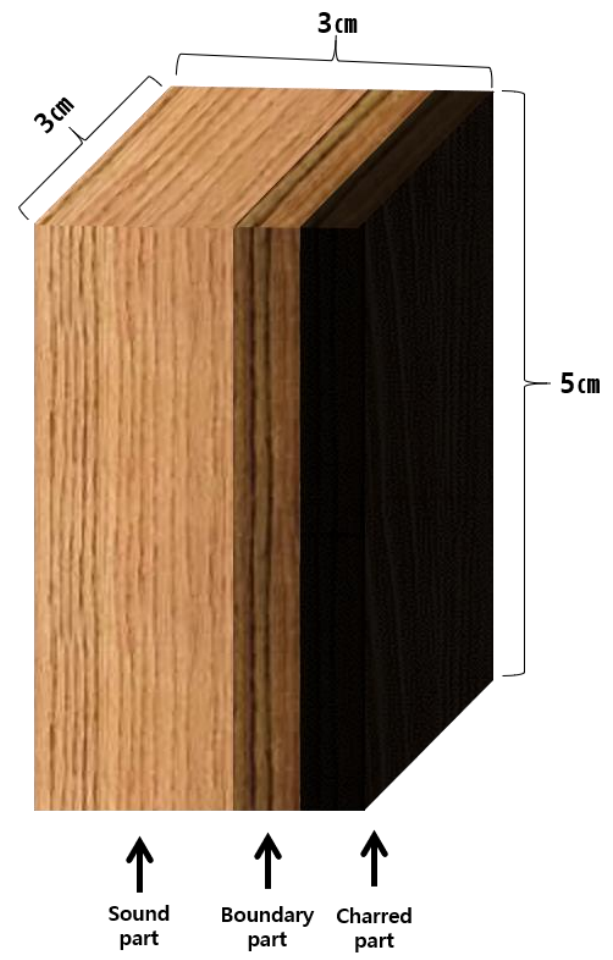

Fig. 3. Sound, boundary, and charred sample

\section{RESULTS AND DISCUSSIONS}

\section{Compressive Strength Analysis of Wood Exposed to High Temperature}

The densities of the unaffected and partially affected glued laminated timber by standardized fire temperature condition were $0.59 \pm 0.08$ and $0.52 \pm 0.09 \mathrm{~g} / \mathrm{cm}^{3}$, respectively, and the compressive strengths were measured at $58.8 \pm 9.1 \mathrm{~N} / \mathrm{mm}^{2}$ for unaffected specimen and $47.0 \pm 6.4 \mathrm{~N} / \mathrm{mm}^{2}$ for partially affected specimen (Table 1 ).

Table 1. Characteristic of Samples

\begin{tabular}{|c|c|c|c|c|}
\hline & $\begin{array}{c}\text { Density } \\
\left(\mathrm{g} / \mathrm{cm}^{3}\right)\end{array}$ & $\begin{array}{c}\text { Moisture } \\
\text { Content }(\%)\end{array}$ & $\begin{array}{c}\text { Average Annual Ring } \\
\text { Width }(\mathrm{mm})\end{array}$ & $\begin{array}{c}\text { Compressive } \\
\text { Strength }\left(\mathrm{N} / \mathrm{mm}^{2}\right)\end{array}$ \\
\hline $\begin{array}{c}\text { Sound } \\
\text { layer }\end{array}$ & $0.59 \pm 0.08$ & & $5.2 \pm 1.7$ & $58.8 \pm 9.1$ \\
\hline $\begin{array}{c}\text { Charred } \\
\text { layer }\end{array}$ & $0.52 \pm 0.09$ & $7.91 \pm 0.3$ & $4.6 \pm 1.3$ & $47.0 \pm 6.4$ \\
\cline { 1 - 2 } & & & \\
\cline { 5 - 5 }
\end{tabular}

To estimate the contribution of the boundary layer to the compressive strength, the strength was compared with that of the sound layer only and that of the sound and boundary layer inclusive.

Table 2 shows the compressive load, loaded area, and compressive strength of specimens including sound wood and charred parts. The compressive strength of sound 
wood was the basis of the analysis of the boundary part's contribution to the compressive load bearing. The effective load bearing area of the charred specimen to support compressive load was re-calculated based on the compressive strength of sound wood. In other words, the compressive strength of specimens including and excluding boundary areas was re-calculated. The calculated compressive strength based on the sound wood area only in the charred wood sample was $14 \%$ higher than that of tested sound wood. Calculated compressive strength including boundary area was $8 \%$ lower than the tested sound wood compressive strength. The result shows an obvious contribution of the boundary part of charred specimen to support compression load.

Based on the increase in compressive strength, the compressive load bearing area in the charred wood was recalculated as $690 \mathrm{~mm}^{2}$ (Table 2). The charred thickness contributing to the load bearing performance at the boundary part was calculated as 4.5 $\mathrm{mm}$. The carbonization mechanism of wood is a chemical and physical change by high temperature exposure. Because the conduction of temperature is one-dimensional, the measurement of charred thickness by the visual method may conclude disregarding the role of load-bearable boundary part of wood specimen. Therefore, it may be appropriate to reduce the charred thickness by $4.5 \mathrm{~mm}$ of the visually evaluated charred thickness (Fig. $5)$.

Table 2. Analyzation of Load Bearing Area

\begin{tabular}{|c|l|l|l|l|}
\hline & $P_{\max }(\mathrm{N})^{*}$ & Area $\left(\mathrm{mm}^{2}\right)^{*}$ & $\begin{array}{l}\text { Compressive } \\
\text { strength }\left(\mathrm{N} / \mathrm{mm}^{2}\right)^{*}\end{array}$ & $\begin{array}{l}\text { Calculated load bearing } \\
\text { area }\left(\mathrm{mm}^{2}\right)\end{array}$ \\
\cline { 1 - 4 } Sound wood & 53526 & 910.3 & $\begin{array}{l}58.8 \\
(100 \%)\end{array}$ & 690.0 \\
\cline { 1 - 3 } $\begin{array}{l}\text { Charred wood } \\
\text { (Sound+Boundary } \\
\text { Area) }\end{array}$ & \multirow{2}{*}{40578} & 748.8 & $\begin{array}{l}54.2 \\
(92 \%)\end{array}$ & \begin{tabular}{l}
$P_{\text {max }}$ \\
\cline { 1 - 3 } $\begin{array}{l}\text { Charred wood only } \\
\text { (Sound Area) }\end{array}$
\end{tabular} \\
\cline { 3 - 4 } & 609.8 & $\begin{array}{l}67.3 \\
(114 \%)\end{array}$ & $\frac{40578 \mathrm{~N}}{58.8 \mathrm{~N} / \mathrm{mm}^{2}}$ \\
\hline
\end{tabular}

*Average of 21 samples

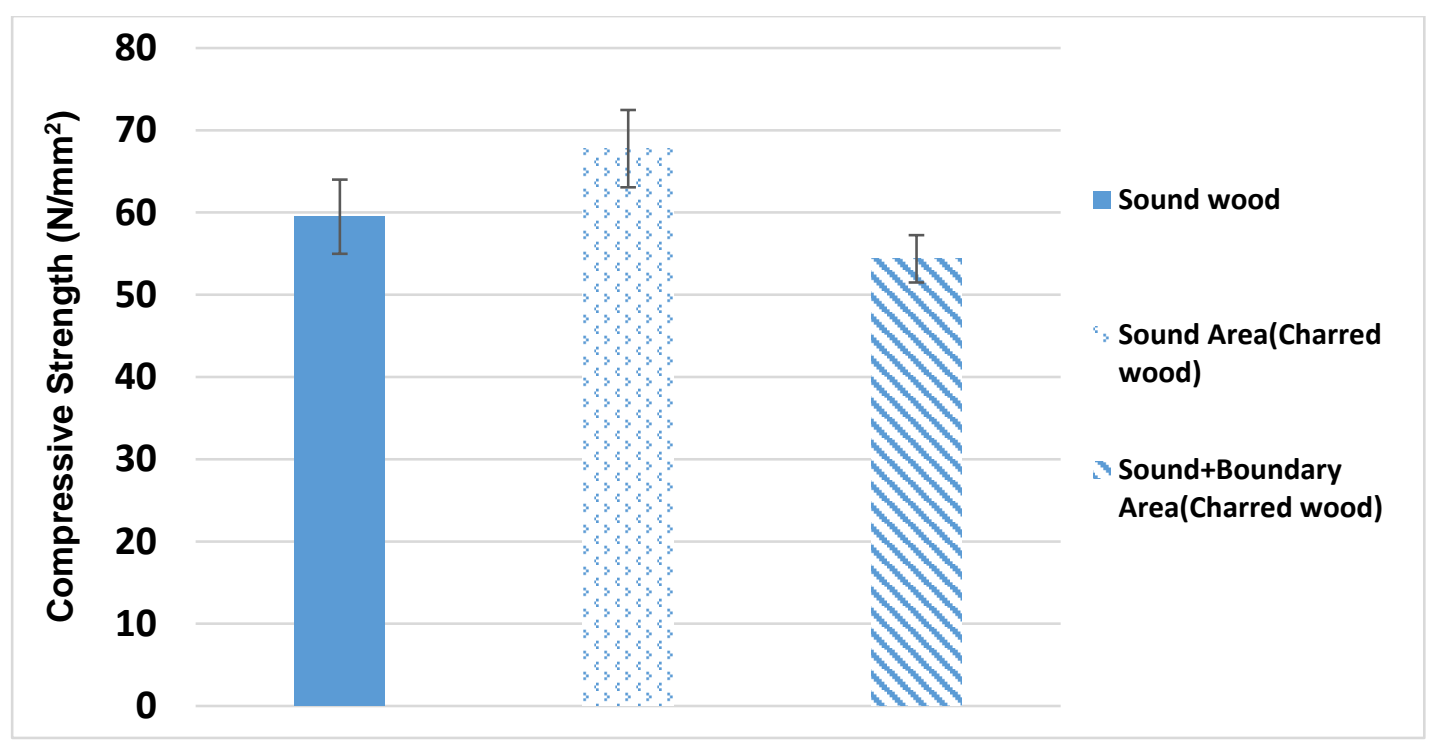

Fig. 4. Relationship between compressive strength and load bearing area 


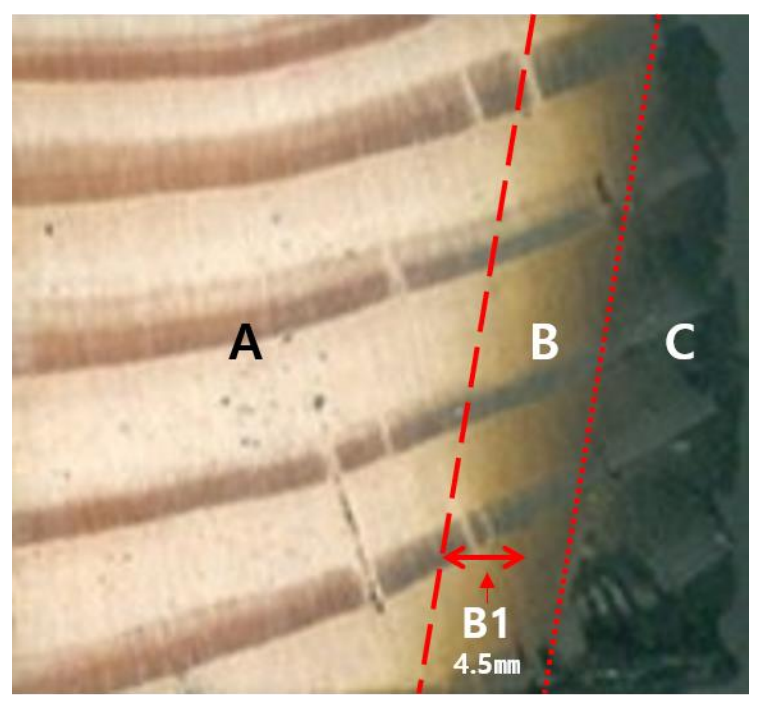

Fig. 5. Effective charred area analyzed by compressive strength comparison (A: Sound area, B: Boundary area, B1: Load bearing $(4.5 \mathrm{~mm})$, C: Charred Area)

\section{Cell Wall Changes under Standardized Fire Temperature Condition}

In order to observe the changes of the cell walls under the standardized fire temperature conditions of Japanese larch, the sound, boundary, and charred layers were separated from the cross section of the test specimen and observed by optical microscope (Fig. 6). Both the earlywood and the latewood showed tendencies for decreases in the thickness of the cell wall due to exposure to high temperatures. In particular, the decrease tendency of the latewood area was obvious. The thickness of the latewood cell wall was measured to be $6.1 \mu \mathrm{m}$ on average at the sound layer, $4.0 \mu \mathrm{m}$ on the boundary layer, and $3.3 \mu \mathrm{m}$ on the charred layer.

When wood is burned, the walls and radial tissue of the tracheid cell are deformed, and the wall pits are widened due to drying process (Awoyemi and Jones 2011). There is also an increase in cell wall separation and cleavage (Lee and Kim 2010). The charcoal manufactured at temperatures above $600{ }^{\circ} \mathrm{C}$ produces many voids due to excessive shrinkage (Kwon and Kim 2007). Changes in cell walls in the tracheid, which account for $90 \%$ of coniferous species, have a significant impact on compressive strength (Oh 1997). Therefore, the difference in compressive strength between the sound and the charred layer in this study was caused by the degraded cell wall thickness of the boundary layer.

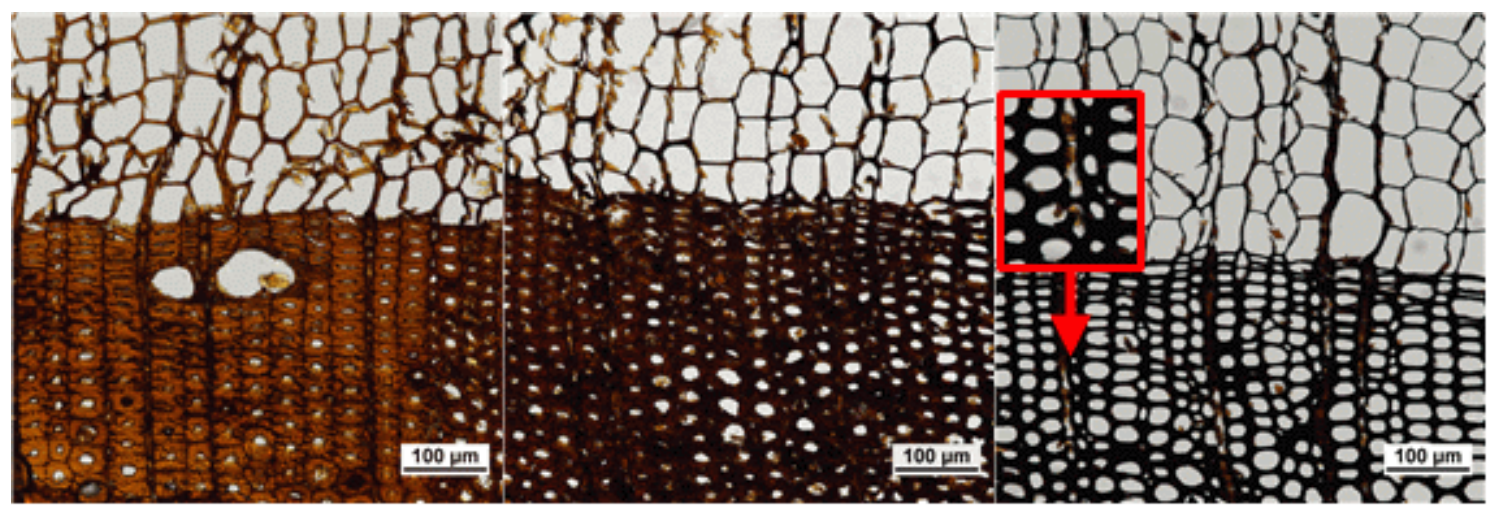

Fig. 6. Tracheid wall variation by high temperature (Sound(a), Boundary(b), Char(c)) 


\section{CONCLUSIONS}

1. The compressive strength of test pieces collected from the structural glued laminated timber beam exposed to the standardized fire temperature for two hours was analyzed, and it was confirmed that there was residual strength of about $14 \%$ in the boundary area between sound and charred part. Therefore, the thickness of charred part should be approximately $4.5 \mathrm{~mm}$ less than the charred thickness measured visually.

2. The cell wall thickness between sound-, boundary- and charred-part exposed to high temperature was observed under a microscope. The higher the temperature, the thinner the tracheid cell wall became, and the radial tissue was broken down. The transformation of the boundary part of these microstructures progressed gradually until full carbonization of wood occurred.

3. Based on compressive strength test of specimens exposed to high temperature and observation of the thickness and shape of tracheid wall in the boundary part, the current visual assessment of charred thickness measurement is safe in terms of structural aspect but not efficient in terms of wood utilization point of view due to exception of loadcarrying area of the member.

\section{REFERENCES CITED}

ASTM D 143-14 Standard Test Methods for Small Cleat Specimens of Timber.

Awoyemi, L., and Jones, I. (2011). "Anatomical explanations for changes in properties of western red cedar (Thuja plicata) wood during heat treatment," Wood Science and Technology 45, 261-267. DOI: 10.1007/s00226-010-0315-9

Kim, Y. S., Kim. G. H., and Kim, Y.S. (2019). Wood Conservation Science, Chonnam National University Press, Gwangju, South Korea.

Kwon, S. M., and Kim, N. H. (2007). "Investigation of carbonization mechanism of wood(II)," Journal of Korean Wood Science and Technology 35(3), 45-52.

KSF 1611-3 (2008). "Fire resistance performance for elements of building constructionPart 3: Beams and columns made of structural glued laminated timber," Korean Standard and Certification, Seoul, South Korea.

KS F 3021-2013 Structural Glued Laminated Timber

Lee, D. Y., and Kim, B. R. (2010). "Analysis of functional characteristics of the commercial wood charcoal in Korea," Journal of Korean Wood Science and Technology 38(6), 480-489. DOI: 10.5658/WOOD.2010.38.6.480

Oh, S. W. (1997). "Relationship between compression strength parallel to grain and anatomical characters in Pinus densiflora S. et Z," Journal of Korean Wood Science and Technology 25(5), 27-32.

Ragland, K. W., and Aerts, D. J. (1991). "Properties of wood for combustion analysis," Bioresource Technology 37, 161-168. DOI: 10.1016/0960-8524(91)90205-X

Wang, X. (2010). "Heat sterilization of wood," in: Wood Handbook: Wood as an Engineering Material, U.S. Department of Agriculture Forest Service, Madison, WI.

White, R. (2000). "Charring rate of composite timber products," in: Proceedings of the $4^{\text {th }}$ International Wood and Fire Safety Conference, Zvolen, Slovakia, pp. 353-363. 
Xing, D., and Li, J. (2014). "Effect of heat treatment on thermal decomposition and combustion performance of Larix spp. wood," BioResources 9(3), 4274-4287. DOI: 10.15376/biores.9.3.4274-4287

Xu, Q., Chen, L., Harries, K. A., Zhang, F., Liu, Q., and Feng, J. (2015). “Combustion and charring properties of five common constructional wood species from cone calorimeter tests," Construction and Building Materials 96, 416-427. DOI: 10.1016/j.conbuildmat.2015.08.062

Article submitted: September 14, 2021; Peer review completed: November 14, 2021; Revised version received: November 27, 2021; Accepted: December 15, 2021; Published: January 11, 2022.

DOI: 10.15376/biores.17.1.1485-1493 